\title{
SIMULTANEOUS TRACE LEVEL DETERMINATION OF BENZENE AND 1, 2-DICHLOROETHANE BY GC-HS/GC-MS IN SEVERAL PHARMACEUTICAL DRUG SUBSTANCES
}

\author{
SAYEEDA SULTANA* ${ }^{*}$ BALAJI NAGARAJAN² \\ Department of Chemistry, St. Peter's Institute of Higher Education and Research, Avadi, Chennai 600054, Tamil Nadu, India \\ Email: chemistry@stpetersuniversity.org
}

Received: 26 Mar 2018, Revised and Accepted: 19 Nov 2018

\section{ABSTRACT}

Objective: We herein report the simultaneous trace level determination of benzene and 1,2-dichloroethane in several active pharmaceutical substances by GC-HS (gas chromatograph-head space) using a DB-624 column.

Methods: This GC-HS method was developed based on an oven-programmed approach using nitrogen gas as the mobile phase. Our method is also compatible with the GC-MS (gas chromatography-mass spectrometry) technique using helium as the mobile phase instead of nitrogen. The successful separation of benzene and 1,2-dichloroethane was established by confirmation of their corresponding specific molecular masses.

Results: The retention time of benzene and 1,2-dichloroethane were found to be 34.8 min and 35.6 min, respectively. The linearity was found in the range of concentration of $0.63-4.22 \mathrm{ppm}$ and $1.49-9.96 \mathrm{ppm}$ for benzene and 1,2-dichloroethane. The detection limit and quantification limit for benzene were 0.2 and $0.6 \mathrm{ppm}$, while those of 1,2-dichloroethane were $0.6 \mathrm{ppm}$ and $1.5 \mathrm{ppm}$. These values were calculated using our developed method with respect to the test concentration of $500 \mathrm{mg} / \mathrm{ml}$. The recovery of benzene and 1,2-dichloroethane were found to be $89-110 \%$ and $91-$ $105 \%$, respectively for the various pharmaceutical drug substances. The specificity of the method was studied using 20 solvents which include benzene and 1,2-dichloroethane.

Conclusion: We expect that our method will be applicable for the simultaneous trace level determination of benzene and 1,2-dichloroethane during the control of manufacturing processes, and for use in rapid analysis for quality control in the pharmaceutical industry. Finally, this method was validated according to the International Conference on Harmonization (ICH) Validation Guidelines Q2 (R1).

Keywords: GC, GC-MS DB-624, Benzene, 1,2-dichloroethane, Class-1 solvent, Pharmaceutical substance

(C) 2019 The Authors. Published by Innovare Academic Sciences Pvt Ltd. This is an open-access article under the CC BY license (http://creativecommons.org/licenses/by/4.0/) DOI: http://dx.doi.org/10.22159/ijap.2019v11i1.28983

\section{INTRODUCTION}

Benzene (fig. 1) is known to cause central nervous system depression in addition to destroying bone marrow, which in turn leads to damage to the hematopoietic system. In addition, benzene has been demonstrated to be a human carcinogen (i.e., lymphatic and hematopoietic cancers), while in animal studies, Zymbal gland tumors, preputial gland tumors, skin carcinomas, mammary gland tumors, and leukemia have been reported. Although positive chromosomal aberration and DNA adducts tests have been recorded, the results of other mutagenicity tests were negative. From the data of human leukemia and benzene exposure correlations, a daily intake of $0.02 \mathrm{mg}$ was found to be associated with a lifetime excess cancer risk of $10^{-5}$ (IRIS), and we note that the guideline value for benzene is $0.02 \mathrm{mg} / \mathrm{d}$ (2 ppm) [1-5].

Repeated exposure to 1,2-dichloroethane (fig. 1) has been reported to induce, nausea, abdominal pain, irritation of mucous membranes, dysfunction of liver and kidney and neurological disorders. In addition, the depression of leukocytes, antibody-forming cells, and cellular immunity was also found in mice, while necrosis of the cerebellum and hyperplasia was observed in addition to inflammation of the forestomach in male rats after oral administration. Although there is no evidence of carcinogenicity in humans, forestomach cancer, hemangiosarcoma, breast cancer, uterine cancer, and respiratory tract cancer were found in rats and mice following gavage treatment. The evidence reported to date, therefore, indicates that 1,2-dichloroethane is potentially genotoxic, and excess cancer risk of $10^{-5}$ was reported at exposures of 0.05 $\mathrm{mg} / \mathrm{d}$ for $50 \mathrm{~kg}$ human based on hemangiosarcoma using a linearized multistage model without body surface correction. The guideline value for 1,2-dichloroethane is $0.05 \mathrm{mg} / \mathrm{d}$ (5 ppm) [1-5].

To date, the detection and quantification of benzene and 1,2dichloroethane have been using only gas chromatography-mass spectrometry (GC-MS) techniques [6-28]. However, previous reports in this area focus on the analysis of the benzene and do not address the detection or quantification of 1,2-dichlorethane.
Indeed, the simultaneous trace level determination of benzene and 1,2-dichloroethane in pharmaceutical drug substances has yet to be reported, and so we selected gas chromatography-head space (GCHS) technique for the purpose of our study in combination with a DB-624 capillary column for the determination of these two compounds in pharmaceutical substances.<smiles>c1ccccc1</smiles><smiles>ClCCCl</smiles>

Benzene

Fig. 1: Chemical structures of benzene and 1,2-dichloroethane

\section{MATERIALS AND METHODS}

\section{Materials}

All samples (i.e., Cabergoline, Celecoxib, Dronedarone hydrochloride, Etravirine, Fesoterodine fumarate, Gabapentin, Irinotecan hydrochloride, Levetricetam and Levothyroxine sodium with the purity of 95\%) were received from Jinan Jiage Biological Technology Co, Ltd., China. Benzene, 1,2-dichloroethane, dimethyl sulfoxide, nbutyl acetate, methanol, ethanol, acetone, isopropyl alcohol, acetonitrile, dichloromethane, n-hexane, ethyl acetate, tetrahydrofuran, toluene, n-heptane, 2-butanone, cyclohexane, methyl tertiary butyl ether, methyl isobutyl ketone and diisopropyl ether solvents were purchased from Fisher Scientific with the purity of $99.5 \%$ (Mumbai, India). The DB-624 GC capillary column was obtained from LCGC (Hyderabad, India). USP grade water was employed throughout and was prepared using a Metrohm Elga 
water purifier (Metrohm, Switzerland). The nitrogen gas cylinder was procured from Indo Gas agencies (Tamil Nadu, India). Development and validation studies were carried out using an Agilent 7890A GC equipped with a G1888 headspace sampler (Agilent Technologies, Singapore). Finally, an Agilent 5973C GC-MS (Agilent technologies, Singapore) was utilized for molecular mass identification of the benzene and 1,2-dichloroethane peaks.

\section{Solution preparation}

\section{Preparation of internal standard solution}

The internal standard (IS) solution was prepared by dissolving nbutyl acetate $(50 \mathrm{mg})$ in dimethyl sulfoxide $(50 \mathrm{ml})$.

\section{Preparation of diluent}

The diluent was prepared by mixing dimethyl sulfoxide $(700 \mathrm{ml})$ with water $(300 \mathrm{ml})$, followed by the addition of IS solution $(2.5 \mathrm{ml})$. The resulting solution was allowed to cool to $25^{\circ} \mathrm{C}$.

\section{Preparation of standard stock solution}

The standard stock solution was prepared by diluting benzene $(50$ $\mathrm{mg})$ and 1,2-dichloroethane $(125 \mathrm{mg})$ in the diluent $(50 \mathrm{ml}) .5 \mathrm{ml}$ portion of this solution was then diluted further to $100 \mathrm{ml}$ using the diluent.

\section{Preparation of standard solution}

The standard solution was then prepared by diluting a portion of the standard stock solution $(2 \mathrm{ml})$ to a final volume of $100 \mathrm{ml}$ using the diluent. The concentrations of benzene and 1,2-dichloroethane in the standard solution were $2.0 \mathrm{ppm}$ and $5.0 \mathrm{ppm}$ respectively, with respect to the analyte concentration.

\section{Preparation of sample solution}

The sample solution was prepared by dilution of sample $(1000 \mathrm{mg})$ in the diluent $(2 \mathrm{ml})$ in a headspace vial. For the preparation of the spiked sample solutions, the sample $(1000 \mathrm{mg})$ was weighed in a headspace vial, and the standard solution was added for $(2 \mathrm{ml})$.

\section{Method}

\section{GC chromatographic conditions}

A DB-624 (60 $\mathrm{m} \times 0.32 \mathrm{~mm} \times 1.8 \mu \mathrm{m})$ column was employed for GC analysis. The oven temperature program began with an initial temperature about $35^{\circ} \mathrm{C}$ (hold time $=45 \mathrm{~min}$ ), Followed by heating to $240{ }^{\circ} \mathrm{C}$ at a rate of $30{ }^{\circ} \mathrm{C} / \mathrm{min}$, and holding at this final temperature for $25 \mathrm{~min}$. The total run time was $76.83 \mathrm{~min}$, a split injection mode with a split ratio of 5: 1 was used, and the column flow rate was $1.5 \mathrm{ml} / \mathrm{min}$. The injection port and detector temperatures were both set at $240{ }^{\circ} \mathrm{C}$.

\section{HS Chromatographic conditions}

In terms of the HS conditions, the oven temperature was $110{ }^{\circ} \mathrm{C}$, loop temperature was $175^{\circ} \mathrm{C}$, and the transfer line temperature was $175^{\circ} \mathrm{C}$. A cycle time of $85 \mathrm{~min}$ was employed, along with vial equilibration time of $60 \mathrm{~min}$, a vial pressurization time of $1 \mathrm{~min}$, a loop filling time of $0.5 \mathrm{~min}$, a loop equilibration time of $0.5 \mathrm{~min}$, and an injection time of $1 \mathrm{~min}$. The vial pressure was maintained at 15 psi.

\section{Other general chromatographic conditions}

Nitrogen and helium were used as the mobile phase for GC-HS and GC-MS analysis respectively. All other parameters were as described for GC-HS above. Each headspace vial was closed tightly with PTFE septum and sealed by the crimping of an aluminium cap. The vials were introduced into the chromatograph using a headspace auto sampler. For the specificity study, desired solvent $(10-20 \mathrm{mg})$ was added to a headspace vial with the diluent. Each solvent vial was closed tightly with PTFE septum and sealed by the crimping of an aluminium cap. The chromatograms of the blank and standard solutions are shown in fig. 2.

a) Blank chromatogram

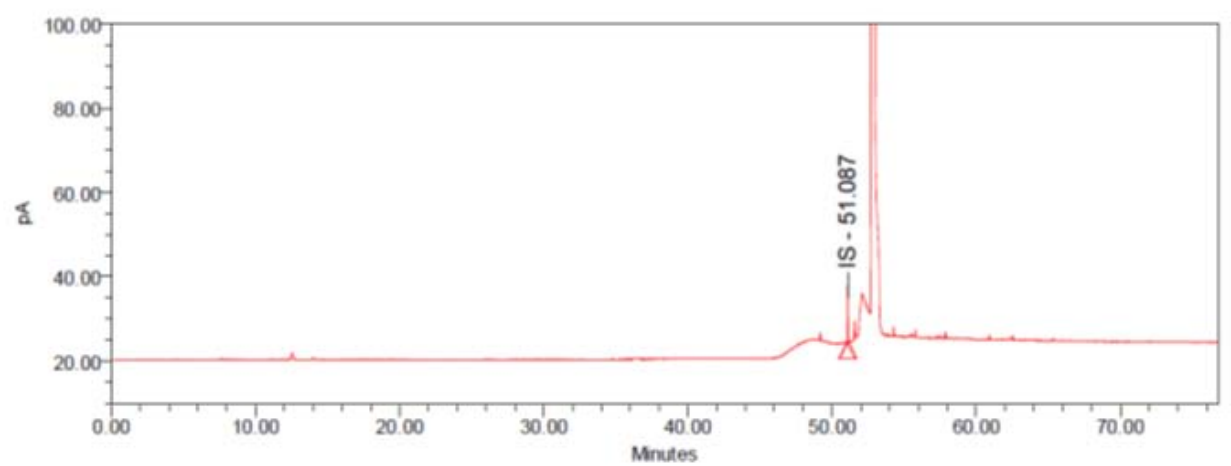

b) Standard chromatogram

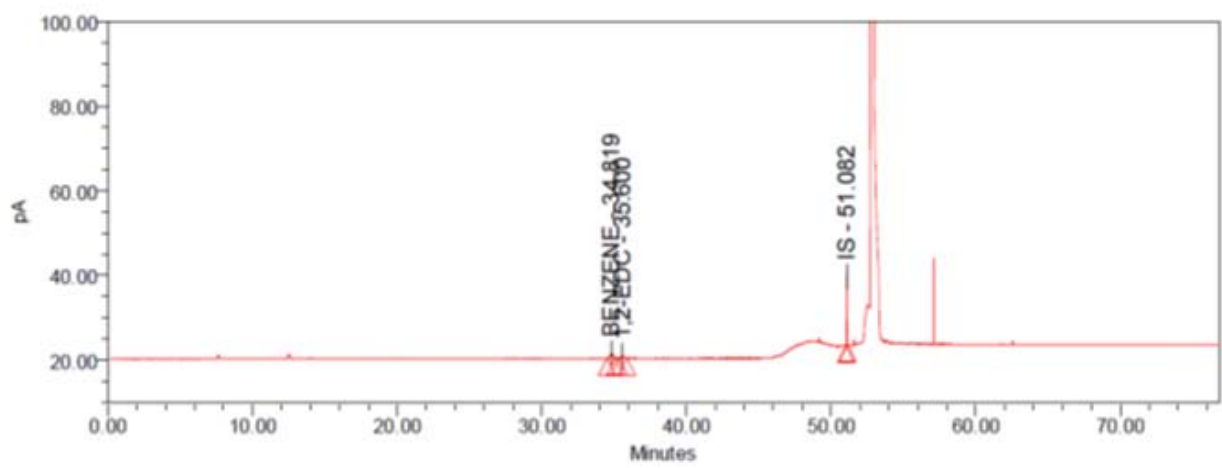

Fig. 2: Chromatograms of (a) the blank and (b) the standard solutions 


\section{RESULTS AND DISCUSSION}

\section{Development}

In recent years, several trials have been performed involving the investigation of different capillary stationary phases for the detection of benzene [6-28]. However, we selected the DB-624 capillary column as the stationary phase for our study due to its unique properties. The selection of pharmaceutical drug substances was based on the availability and cost. In addition, the solvents employed for the specificity study were selected based on the reported synthetic process of their respective product patents.

The resolution of $<0.8$ was obtained between benzene and 1,2 dichloroethane using 20 and $30 \mathrm{~m}$ capillary GC columns. As the boiling points of benzene and 1,2-dichloroethane are similar. (i.e., $80.1{ }^{\circ} \mathrm{C}$ and $83.5{ }^{\circ} \mathrm{C}$, respectively), increasing the column length was expected to improve the resolution. Thus, a column measuring $60 \mathrm{~m}$ in length with an internal diameter of $0.32 \mathrm{~mm}$ and a particle size of $1.8 \mu \mathrm{m}$ was employed.

\section{Validation}

The system suitability and precision, limit of detection (LOD), limit of quantitation (LOQ), linearity and range, recovery, specificity, robustness, and solution stability of this method for the analysis of benzene and 1,2-dichloroethane were determined as per the ICH validation guidelines Q2, (R1) [29]. Further details regarding each of the above points can be found in the following subsections.

\section{System suitability and precision}

As indicated in table 1, a resolution of 1.9 was established between the benzene and 1,2-dichloroethane upon analysis of the standard solution under the optimized conditions. To determine the precision of this analytical system (i.e., an expression of the closeness of agreement between a series of measurements obtained from multiple sampling of the same homogeneous sample under the prescribed conditions) [29], the standard solution was injected into the chromatograph six times and the percentage relative standard deviation (\%RSD) was calculated. The obtained \%RSD of $<3 \%$ indicates that this system was precise (\%RSD limit $\leq 15 \%$ ) [29], and as such, is suitable for analysis of the benzene and 1,2dichloroethane contents. Further details regarding determination of the system precision are outlined in table 1 below.

\section{Method precision}

To determine the precision of this method, six spiked sample solutions were initially prepared. Using the above-described method, the \% RSD for the benzene and 1, 2-dichloroethane content were $<0.5 \%$ for the method precision (limit $=<5 \%$ ) [29], and these values were within $1.0 \%$ for the intermediate precision when performed by different analysts, on different columns and instruments on different days. These observations, in combination with the detailed results outlined in table 2, indicate that our developed technique was suitably precise for the system of interest.

Table 1: Determination of the system suitability of $\%$ RSD along with resolution and precision for benzene and 1,2-dichloroethane

\begin{tabular}{lll}
\hline \%RSD of peak area ratios & \\
\hline Inj. \# & Benzene & $\mathbf{1 , 2}$-Dichloroethane \\
\hline 1 & 0.5394 & 0.2351 \\
2 & 0.5414 & 0.2335 \\
3 & 0.5464 & 0.2393 \\
4 & 0.5481 & 0.2437 \\
5 & 0.5401 & 0.2472 \\
6 & 0.5471 & 0.2413 \\
Mean & 0.5437 & 0.2400 \\
SD & 0.00 & 0.01 \\
\%RSD & 0.71 & 2.16 \\
Inj. \# & Resolution & \\
1 & 1.9 & \\
\hline
\end{tabular}

*Abbreviations: Each value is represented as the mean+SD of 6 measurements $(\mathrm{n}=6)$, SD: standard deviation, RSD: relative standard deviation, \# Acceptance criteria $<15 \%$.

Table 2: Method and intermediate precision results for benzene and 1,2-dichloroethane

\begin{tabular}{lll}
\hline Preparation No. & Benzene content (ppm) & 1,2-Dichloroethane content (ppm) \\
\hline 1 & 2.145 & 5.151 \\
2 & 2.147 & 5.152 \\
3 & 2.149 & 5.150 \\
4 & 2.150 & 5.153 \\
5 & 2.150 & 5.149 \\
6 & 2.151 & 5.148 \\
Mean & 2.148 & 5.150 \\
SD & 0.00 & 0.00 \\
\%RSD & 0.10 & 0.03 \\
1 & 2.105 & 5.056 \\
2 & 2.107 & 5.025 \\
3 & 2.140 & 5.015 \\
4 & 2.102 & 5.006 \\
5 & 2.109 & 4.998 \\
6 & 2.114 & 5.015 \\
Mean & 2.112 & 5.019 \\
SD & 0.01 & 0.02 \\
\%RSD & 0.65 & 0.40 \\
\hline
\end{tabular}

*Abbreviations: Each value is represented as the mean+SD of 6 measurements $(n=6)$, SD: standard deviation, RSD: relative standard deviation, \# Acceptance criteria $<5 \%$. 


\section{Limit of detection and limit of quantification}

The method detection limit (MDL) and method quantification limit (MQL) (i.e., the LOD and the LOQ) were determined based on the signal to noise $(\mathrm{S} / \mathrm{N})$ ratio method as outlined in the ICH guideline Q2 (R1). Upon injecting the solution sequence of predetermined known concentrations $(0.1-2.5 \mathrm{ppm}$ for benzene and $0.5-5.5 \mathrm{ppm}$ for 1,2-dichloroethane), the $\mathrm{S} / \mathrm{N}$ ratio for the LOD was determined to be 3:1, while that of the LOQ was determined to be 10:1. Thus, the MDL for benzene and 1,2-dichloroethane were 0.2 and $0.5 \mathrm{ppm}$, respectively; the MQL for benzene and 1,2-dichloroethane were 0.6 and $1.5 \mathrm{ppm}$, respectively. These results indicate that our method was sufficiently sensitive for simultaneous trace level determination of the benzene and 1,2-dichloroethane contents in the of pharmaceutical drug substances examined herein.

\section{Linearity and range}

The linearity of an analytical procedure reflects its ability to produce results that are directly proportional to the concentration of an analyte in the sample [29]. In this case, linearity tests were performed from the LOQ to $200 \%$ of this limit for an analyte concentration. The results of this test and the corresponding correlation coefficients are shown in table 3 , while the linearity plots are provided in fig. 3 and 4. As shown, the correlation coefficient was close to 1 , indicating that the developed method was indeed linear. Furthermore, the statistical linear regression results indicate that the validated method was linear for pharmaceutical drug substances examined herein, and that this linearity was satisfactory over the defined concentration range (i.e., $0.6-4.2 \mathrm{ppm}$ for benzene and 1.5-9.9 ppm for 1,2-dichloroethane).

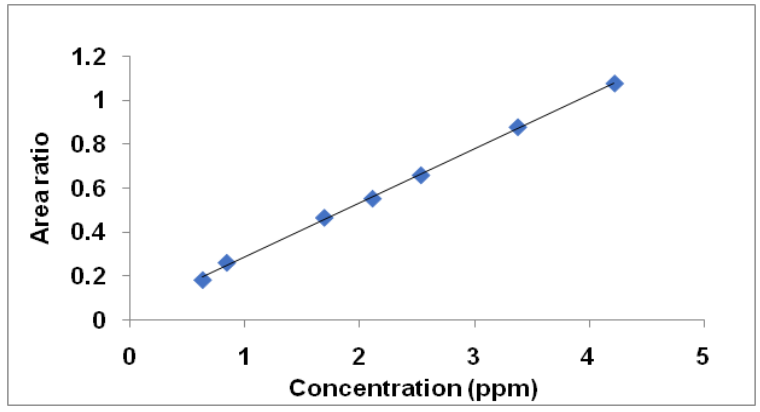

Fig. 3: The linearity plot for benzene

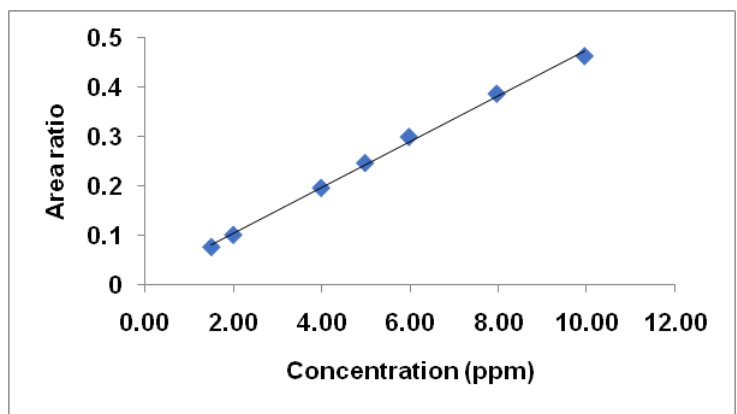

Fig. 4: The linearity plot for 1,2-dichloroethane

Table 3: Linearity data for benzene and 1,2-dichloroethane

\begin{tabular}{llll}
\hline Benzene & & & Concentration (ppm) \\
\hline Sample No. & \% Level & 0.63 & 0.1808 \\
\hline 1 & LOQ & 0.84 & 0.2595 \\
2 & 40 & 1.69 & 0.4645 \\
3 & 80 & 2.11 & 0.5517 \\
4 & 100 & 2.53 & 0.6581 \\
5 & 120 & 3.38 & 0.8772 \\
6 & 160 & 4.22 & 1.0761 \\
7 & 200 & 0.246 & \\
Slope & & 0.0386 & \\
Y-intercept & & 0.9991 & Area ratio \\
Correlation co-efficient squared $\left(\mathrm{r}^{2}\right)$ & & 0.0756 \\
1,2-Dichloroethane & & Concentration (ppm) & 0.1002 \\
Sample No. & \% Level & 1.49 & 0.1954 \\
\hline 1 & LOQ & 1.99 & 0.2458 \\
2 & 40 & 3.98 & 0.2988 \\
3 & 80 & 4.98 & 0.3863 \\
4 & 100 & 5.97 & 0.4626 \\
5 & 120 & 7.97 & \\
6 & 160 & 9.96 & \\
7 & 200 & 0.0464 & \\
Slope & & 0.011 & \\
Y-intercept & & 0.9975 & \\
Correlation co-efficient squared $\left(\mathrm{r}^{2}\right)$ & & \\
\hline
\end{tabular}

*Abbreviations: Each value is an average of 7 measurements ( $\mathrm{n}=7)$, LOQ: limit of quantitation, ppm: parts per million, \# Acceptance criteria $\left(\mathrm{r}^{2}\right)>0.98$.

\section{Accuracy}

The accuracy of an analytical procedure indicates the closeness of understanding between the quality which is acknowledged either as a true conventional value or an accepted reference value and the value found [29]. For quantitative approaches, a minimum of nine determinations across a specified range should be obtained [29]. In our case, the accuracy (\%) for detecting the benzene and 1, 2dichloroethane in LOQ and in 50\%, 100\% and 150\% levels for the various pharmaceutical drug substances were $89-110 \%$ and $91-$ $105 \%$, respectively. These results indicate that our developed method was accurate for the present analytical system, as the mean accuracy value was within the standard $80-120 \%$ limit.
Furthermore, the accuracy of this method at the LOQ and at 50, 100, and $150 \%$ levels of benzene and 1, 2-dichloroethane is outlined in tables 4 and 5 .

\section{Specificity}

Specificity is the ability to assess the analyte unequivocally in the presence of other components that may be present in the mixture. These may typically include solvents, impurities, degradants, and matrix components, among others [29]. Thus, the specificity of our method was determined by examination of the interference. No interference was observed either from the blank or from all solvents. Furthermore, the solvent spiking results (i.e., with sample spiking) indicate that benzene 
and 1, 2-dichloroethane were not co-eluted with the other solvents. These results confirm the specificity/homogeneity of our developed method for the detection of benzene and 1, 2-dichloroethane. This was also confirmed by GC-MS, and the mass spectra are given in fig. 5 and 6 .

Table 4: Accuracy of this method for the detection of benzene in various pharmaceutical drug substances (\% recovery)

\begin{tabular}{|c|c|c|c|c|}
\hline Pharmaceutical drug substance & LOQ & $50 \%$ & $100 \%$ & $150 \%$ \\
\hline Cabergoline & $89 \%$ & $92 \%$ & $91 \%$ & $101 \%$ \\
\hline Celecoxib & $92 \%$ & $95 \%$ & $89 \%$ & $93 \%$ \\
\hline Dronedarone hydrochloride & $93 \%$ & $95 \%$ & $100 \%$ & $90 \%$ \\
\hline Etravirine & $96 \%$ & $97 \%$ & $105 \%$ & $99 \%$ \\
\hline Etoricoxib & $97 \%$ & $96 \%$ & $98 \%$ & $98 \%$ \\
\hline Fesoterodine fumarate & $98 \%$ & $93 \%$ & $96 \%$ & $95 \%$ \\
\hline Gabapentin & $101 \%$ & $92 \%$ & $93 \%$ & $99 \%$ \\
\hline Irinotecan hydrochloride & $98 \%$ & $91 \%$ & $89 \%$ & $102 \%$ \\
\hline Levetricetam & $95 \%$ & $94 \%$ & $102 \%$ & $101 \%$ \\
\hline Levothroxine sodium & $93 \%$ & $89 \%$ & $101 \%$ & $110 \%$ \\
\hline
\end{tabular}

*Abbreviations: Each value is an average of 10 measurements (drugs) ( $\mathrm{n}=10)$, LOQ: limit of quantitation, \# Acceptance criteria 80-120\%

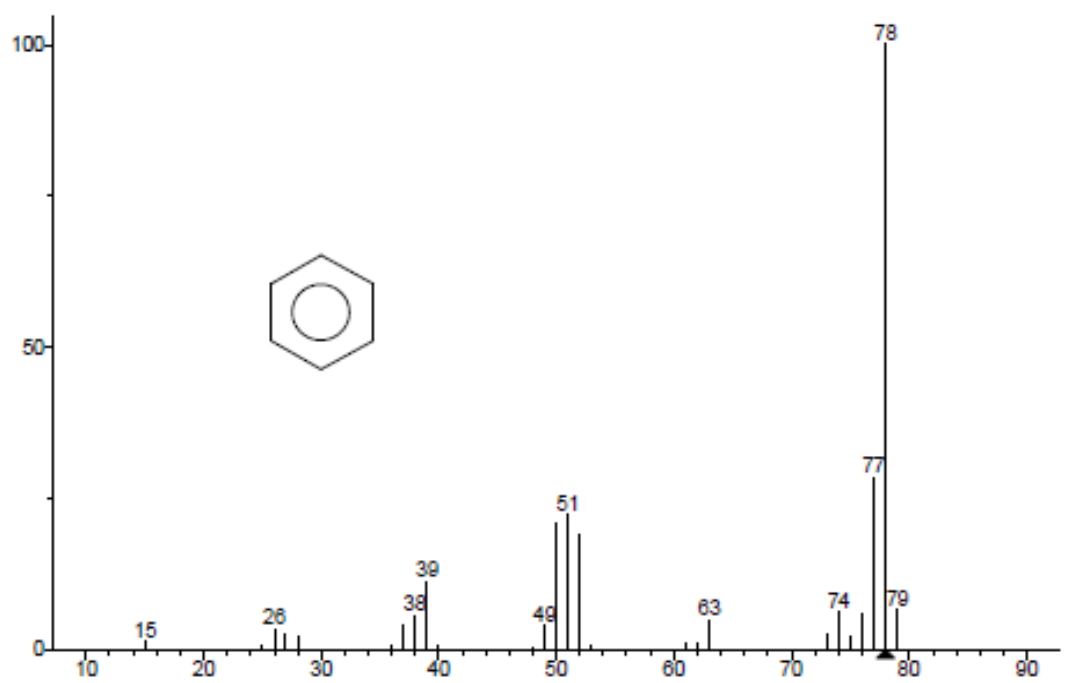

Fig. 5: The mass spectrum of benzene

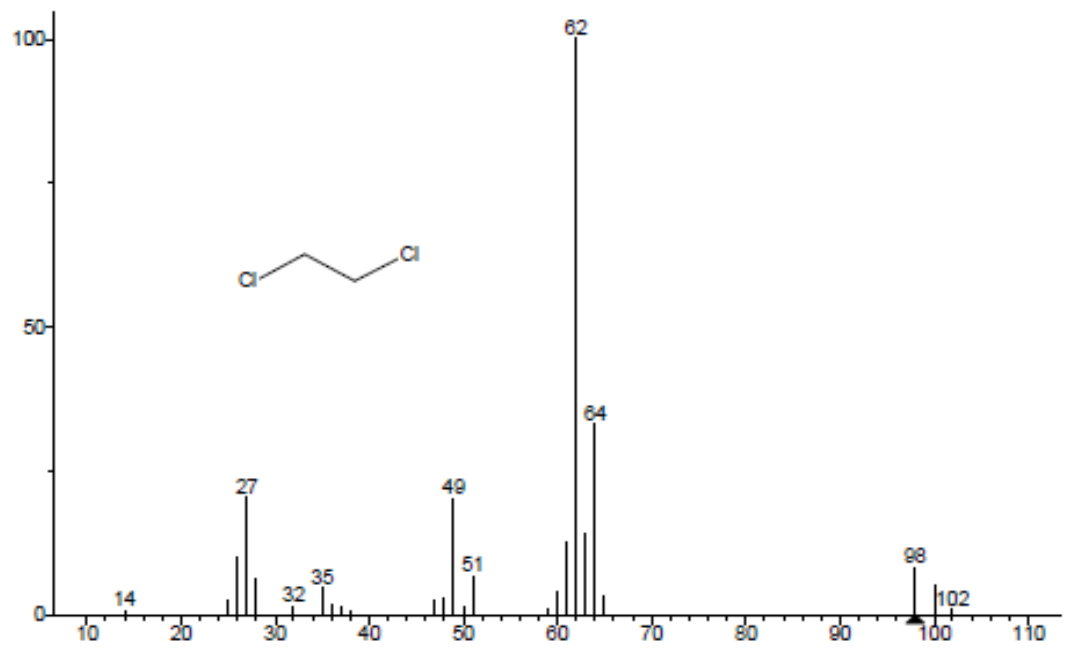

Fig. 6: The mass spectrum of 1,2-dichloroethane

\section{Robustness}

We then examined the effect of chromatographic conditions on the resolution between the benzene and 1,2-dichloroethane. As the original nitrogen gas flow rate was $1.5 \mathrm{ml} / \mathrm{min}$, we varied the flow rate from 1.4 to $1.6 \mathrm{ml} / \mathrm{min}$ to investigate its effect on the resolution.
In addition, the column oven temperature was set at 30,35 , or $40{ }^{\circ} \mathrm{C}$ to examine the effect of temperature.

Finally, the headspace oven temperature was varied between 100 and $120^{\circ} \mathrm{C}$. Interestingly, the resolution was $>1.0$ under all conditions studied, thus demonstrating the robustness of our method. 
Table 5: Accuracy of this method for the detection of 1,2-dichloroethane in various pharmaceutical drug substances (\% recovery)

\begin{tabular}{|c|c|c|c|c|}
\hline Pharmaceutical drug substance & LOQ & $50 \%$ & $100 \%$ & $150 \%$ \\
\hline Cabergoline & $91 \%$ & $96 \%$ & $97 \%$ & $101 \%$ \\
\hline Celecoxib & $102 \%$ & $100 \%$ & $101 \%$ & $98 \%$ \\
\hline Dronedarone hydrochloride & $98 \%$ & $98 \%$ & $102 \%$ & $105 \%$ \\
\hline Etravirine & $88 \%$ & $95 \%$ & $93 \%$ & $98 \%$ \\
\hline Etoricoxib & $91 \%$ & $97 \%$ & $100 \%$ & $102 \%$ \\
\hline Fesoterodine fumarate & $95 \%$ & $102 \%$ & $100 \%$ & $101 \%$ \\
\hline Gabapentin & $101 \%$ & $102 \%$ & $103 \%$ & $100 \%$ \\
\hline Irinotecan hydrochloride & $98 \%$ & $97 \%$ & $101 \%$ & $99 \%$ \\
\hline Levetricetam & $92 \%$ & $101 \%$ & $103 \%$ & $98 \%$ \\
\hline Levothroxine sodium & $97 \%$ & $99 \%$ & $98 \%$ & $100 \%$ \\
\hline
\end{tabular}

*Abbreviations: Each value is an average of 10 measurements (drugs) ( $n=10)$, LOQ: limit of quantitation, \# Acceptance criteria 80-120\%.

\section{Solution stability}

Finally, the solution stability was determined by examination of a freshly prepared standard solution in a sealed vial at $25^{\circ} \mathrm{C}$ over $24 \mathrm{~h}$. The \% Difference between the peak areas of benzene and 1,2dichloroethane at $0 \mathrm{~h}$ and $24 \mathrm{~h}<15 \%$ for standard solution [29]. The obtained results thereby confirm that the standard solution was stable under these conditions.

\section{CONCLUSION}

We herein reported the versatile gas chromatographic method for the simultaneous quantitative determination and separation of benzene and 1,2-dichloroethane in pharmaceutical drug substances. More specifically, a DB-624 column was employed in our precise and accurate method, yielding acceptable and repeatable recoveries in addition to low limits of detection and quantification. This authenticated method is expected to be applicable in the regular analysis of benzene and 1,2-dichloroethane in quality control laboratories of pharmaceutical drug substances. However, further studies are required to decrease the run time of our method, as this was not possible through simply increasing the column flow rate.

\section{ACKNOWLEDGMENT}

The authors acknowledge the support provided by the chemistry department, St. Peter's Institute of Higher Education and Research. This study did not receive any funding.

\section{AUTHORS CONTRIBUTIONS}

All the author have contributed equally

\section{CONFLICTS OF INTERESTS}

The authors declare no conflict of interest

\section{REFERENCES}

1. https://www.fda.gov/downloads/Drugs/GuidanceComplianceReg ulatoryInformation/Guidances/UCM073397.pdf. [Last accessed on 05 Jul 2018].

2. International Conference on Harmonisation (ICH) of Technical Requirements for the Registration of Pharmaceuticals for Human Use, Q3C (R6): Impurities: Guidelines for Residual Solvents, Step 4; 2016.

3. United States Pharmacopoeia, 40, United States Pharmacopeial Convention, Inc, Rockville, MD, USA; 2017.

4. European Pharmacopoeia. 9.0, Council of Europe, Strasbourg, France; 2017.

5. Japanese Pharmacopoeia. 17th ed. Society of Japanese Pharmacopoeia, Tokyo; 2017.

6. Balaji N, Sultana S. Reversed-phase UHPLC enantiomeric separation of rasagiline salts using a Chiralpak® AGP column. Sci Pharm 2017;85:1-13.

7. Grodowska K, Parczewski A. Organic solvents in the pharmaceutical industry. Acta Pol Pharm 2010;67:3-12.

8. Grodowska K, Parczewski A. Analytical methods for residual solvents determination in pharmaceutical products. Acta Pol Pharm 2010;67:13-26.

9. Autry WD, Zheng C, Wolfs K, Yarramraju S, Hoogmartens J, Van Schepdael A, et al. Mixed aqueous solutions as dilution media in the determination of residual solvents by static headspace gas chromatography. J Sep Sci 2011;34:1299-308.

10. Balaji N, Sultana S. Trace level determination and quantification of potential genotoxic impurities in dasatinib drug substance by UHPLC/INFINITY LC. Int J Pharm Pharm Sci 2016;8:209-16.

11. Autry WD, Zheng C, Bugalama J, Wolfs K, Hoogmartens J, Adams $\mathrm{E}$, et al. Liquid paraffin as new dilution medium for the analysis of high boiling point residual solvents with static headspacegas chromatography. J Pharm Biomed Anal 2011;55:1017-23.

12. Autry WD, Wolfs K, Hoogmartens J, Adams E, Van Schepdael A. Improving quantitative gas chromatography-electron ionization mass spectrometry results using a modified ion source: demonstration for a pharmaceutical application. J Chromatogr A 2011;18:4034-8.

13. Weiss AM. Buying prescription drugs on the internet: promises and pitfalls. Cleve Clin J Med 2006;73:282-8.

14. Veronin M, Youan BB. Magic bullet gone astray: medications and the internet. Science 2004;305:481.

15. Balaji N, Sultana S. Ultra-high performance liquid chromatographic determination of genotoxic impurities in febuxostat drug substance and products. Asian J Pharm Clin Res 2017;10:324-30.

16. European Alliance For Access to Safe Medicines; 2018. Available from: www.eaasm.eu. [Last accessed on 05 Jul 2018]

17. WHO. Sixty-second world health assembly item 12.9, Counterfeit medical products; 2009. Available from: http://aps.who.int/gb/ebhwa/pdf files/A62/A62 13-en.pdf. [Last accessed on 05 Jul 2018]

18. Balaji N, Sultana S. GC and GC-MS detection of alkyl mesylates in active pharmaceutical ingredients. Int J Pharm Sci Rev Res 2017;46:88-92.

19. Sacre PY, Deconinck E, Chiap P, Crommen J, Rozet E, Courselle $\mathrm{P}$, et al. Development and validation of a UHPLC-UV method for the detection and quantification of erectile dysfunction drugs and some of their analogues found in counterfeit medicines. J Chromatogr A 2011;1218:6439-47.

20. Deconinck E, Verlinde K, Courselle P, De Beer J. A validated ultra-high pressure liquid chromatographic method for the characterisation of confiscated illegal slimming products containing anorexics. J Pharm Biomed Anal 2012;59:38-43.

21. EN ISO/IEC 17025). General requirements for the competence of testing and calibration laboratories; 2005. Available from: www.iso.org. [Last accessed on 05 Jul 2018].

22. Balaji N, Sultana S. LC determination of diastereomeric impurities of entecavir in drug substances and drug products. Res J Pharm Biol Chem Sci 2016;7:1848-59.

23. Fienberg M. Validation of analytical methods based on accuracy profiles. J Chromatogr A 2007;1158:174-83.

24. M Feinberg, M Laurentie. A global approach to method validation and measurement uncertainty. Accredit Qual Assur 2006;11:3-9.

25. De Backer B, Debrus B, Lebrun P, Theunis L, Dubois N, Decock $\mathrm{L}$, et al. Innovative development and validation of an HPLC/DAD method for the qualitative and quantitative determination of major cannabinoids in cannabis plant material. J Chromatogr B 2009;877:4115-24.

26. Balaji N, Sultana S. Sensitive determination of related substances in pioglitazone hydrochloride by HPLC. Int J Appl Pharm 2017;9:34-41. 
27. De Beer J0, De Beer TR, Goeyens L. Assessment of quality performance parameters for straight line calibration curves related to the spread of the abscissa values around their mean. Anal Chim Acta 2007;584:57-65.

28. De Beer J0, Naert C, Deconinck E. The quality coefficient as performance assessment parameter of straight line calibration curves in relationship with the number of calibration points. Accredit Qual Assur 2012;17:265-74.

29. International Conference on Harmonisation (ICH) of Technical Requirements for the Registration of Pharmaceuticals for Human Use, Q2 (R1): Impurities: Guidelines for Residual Solvents; 2005. 